\title{
Map of Debris Flows Caused by Rainfall During 1996 in Parts of the Reedsport and Deer Head Point Quadrangles, Douglas County, Southern Coast Range, Oregon
}

By Jeffrey A. Coe, John A. Michael, and Marianela Mercado Burgos

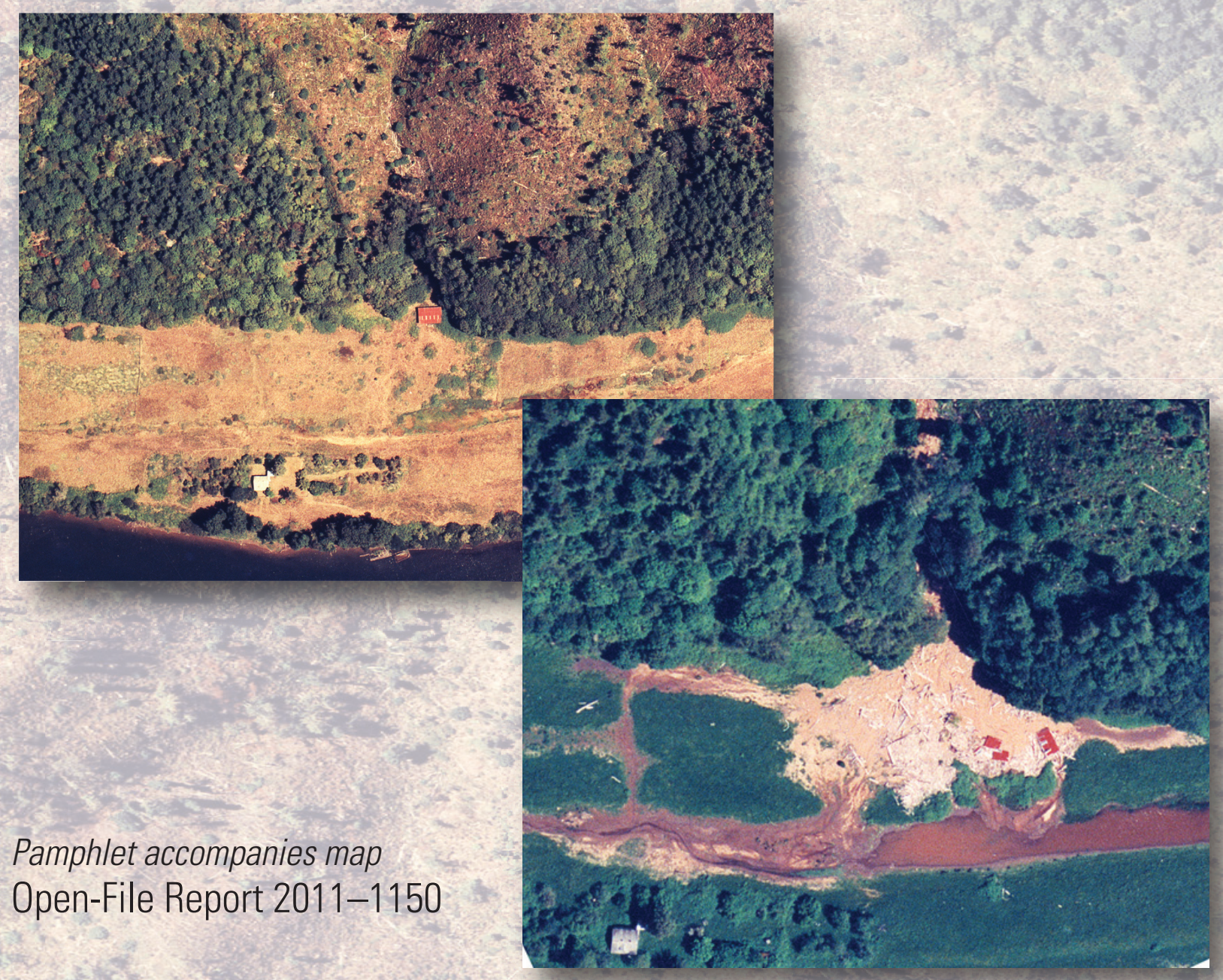

U.S. Department of the Interior

U.S. Geological Survey 
Cover: Aerial photographs of a debris fan taken before and after a debris flow in the map area. Photograph on the left was taken on July 29, 1992. Photograph on the right was taken May 17, 1997. The horozontal distance between the two buildings is about $200 \mathrm{~m}$. The debris fan is located along the right edge of the map, just north of the Umpqua River. Photographs by the U.S. Bureau of Land Management. 


\title{
U.S. Department of the Interior KEN SALAZAR, Secretary
}

\author{
U.S. Geological Survey \\ Marcia K. McNutt, Director
}

\section{U.S. Geological Survey, Reston, Virginia 2011}

For product and ordering information:

World Wide Web: http://www.usgs.gov/pubprod

Telephone: 1-888-ASK-USGS

For more information on the USGS - the Federal source for science about the Earth, its natural and living resources, natural hazards, and the environment:

World Wide Web: http://www.usgs.gov

Telephone: 1-888-ASK-USGS

\section{Suggested citation:}

Coe, J.A., Michael, J.A., and Burgos, M.M., 2011, Map of debris flows caused by rainfall during 1996 in parts of the Reedsport and Deer Head Point quadrangles, Douglas County, southern Coast Range, Oregon: U.S. Geological Survey Open File Report 2011-1150, 9 p. pamphlet, 1 sheet, scale 1:12,000.

Any use of trade, product, or firm names is for descriptive purposes only and does not imply endorsement by the U.S. Government.

Although this information product, for the most part, is in the public domain, it also contains copyrighted material as noted in the text. Permission to reproduce copyrighted items for other than personal use must be secured from the copyright owner. 


\section{Contents}

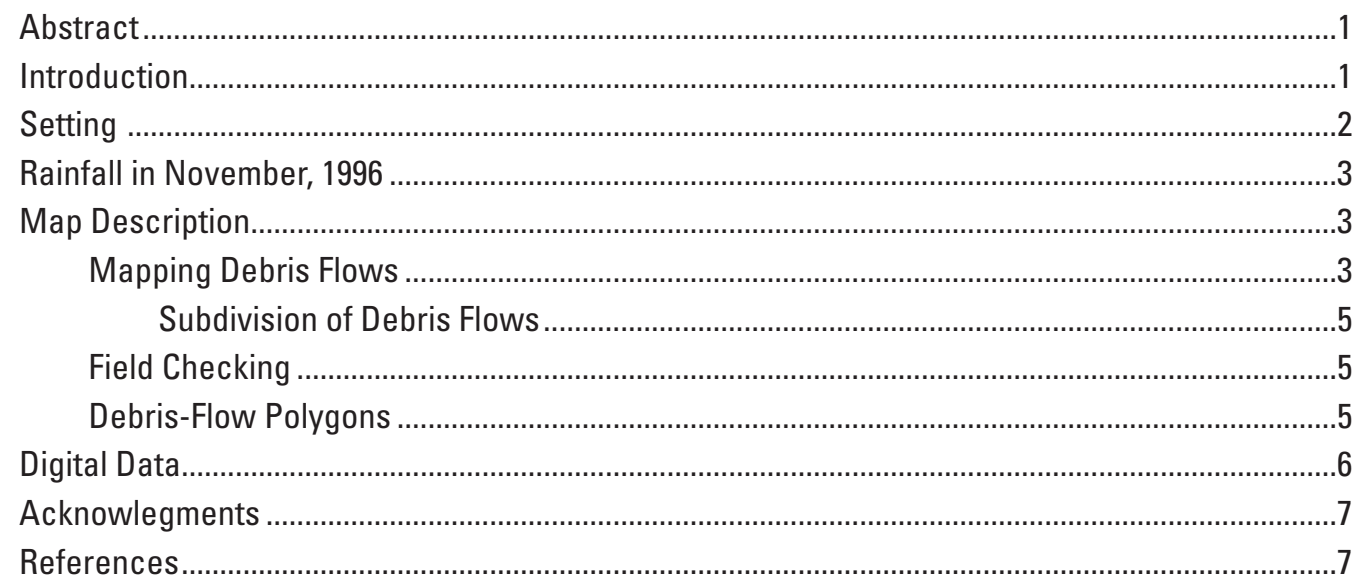

\section{Figures}

1. Location of the map area with respect to the Reedsport and Deer Head Point $1: 24,000$-scale quadrangles.

2. (A) Cumulative precipitation during 1996 and 1997, and (B) cumulative hourly precipitation during the Nov. 17-19 rain storm................................................................................................4

3. Example of a 1:12,000-scale aerial photograph used for mapping.............................................

\section{Table}

1. Rain-gage station information

\section{Map}

1. Debris flows caused by rainfall during 1996 in parts of Reedsport and Deer Head Point quadrangles 


\section{Conversion Factors}

\section{SI Inch/Pound}

\begin{tabular}{lll}
\hline \multicolumn{1}{c}{ Multiply } & By & To obtain \\
\hline millimeter $(\mathrm{mm})$ & Length & \\
meter $(\mathrm{m})$ & 0.03937 & inch (in) \\
kilometer $(\mathrm{km})$ & 3.281 & foot $(\mathrm{ft})$ \\
& 0.6214 & mile (mi) \\
square kilometer $\left(\mathrm{km}^{2}\right)$ & Area & \\
square meter $\left(\mathrm{m}^{2}\right)$ & 0.3861 & square mile $\left(\mathrm{mi}^{2}\right)$ \\
& 0.0002471 & acre
\end{tabular}

Vertical coordinate information is referenced to the North American Vertical Datum of 1988 (NAVD 88)

Horizontal coordinate information is referenced to the North American Datum of 1983 (NAD 83), HARN

Elevation, as used in this report, refers to distance above the vertical datum. 


\title{
Map of Debris Flows Caused by Rainfall During 1996 in Parts of the Reedsport and Deer Head Point Quadrangles, Douglas County, Southern Coast Range, Oregon
}

\author{
By Jeffrey A. Coe, ${ }^{1}$ John A. Michael, ${ }^{1}$ and Marianela Mercado Burgos ${ }^{2}$
}

'U.S. Geological Survey, MS 966, Denver Federal Center, Denver, Colo. 80225

2University of Puerto Rico, Mayagüez, Puerto Rico

\section{Abstract}

This 1:12,000-scale map shows an inventory of debris flows caused by rainfall during 1996 in a $94.4 \mathrm{~km}^{2}$ area of the southern Coast Range of Oregon. This map and associated digital data are part of a larger U.S. Geological Survey study of debris flows in the southern Coast Range. Available evidence indicates that the flows were triggered by a rain storm that occurred between November 17 and 19. The closest rain gage in the Coast Range (Goodwin Peak) recorded 245 $\mathrm{mm}$ during the storm. Maximum rainfall intensity during the storm was $13.2 \mathrm{~mm} / \mathrm{hr}$ on November 18. Debris flows were photogrammetrically mapped from 1:12,000-scale aerial photographs flown in May 1997. The inventory is presented on imagery derived from LiDAR data acquired in 2008. We classified mapped debris flows into four categories based on the type of debris-flow activity: (1) discrete slide source areas, (2) predominantly erosion, (3) predominantly transport or mixed erosion and deposition, and (4) predominantly deposition. Locations of woody-debris jams are also shown on the map. The area encompassed by debris flows is 2.1 percent of the $94.4 \mathrm{~km}^{2}$ map area.

\section{Introduction}

In the Coast Range of Oregon, nearly all drainage basins periodically generate debris flows (for example, see May and Gresswell, 2004). These flows often affect natural resources and roads and structures both within, and at the mouths of basins (Hofmeister, 2000; Squier and Harvey, 2000; Mills and Hinkle, 2001). During 1996, two major storms, one in February and one in November, produced widespread debris flows in the Coast Range. In the southern Coast Range, most debris-flow activity in 1996 was triggered by the November storm (Robison and others, 1999; Wiley, 2000). Two debris flows in November caused five fatalities (Mills and Hinkle, 2001). Two additional storms affected southern Oregon in December 1996, and January, 1997, but the debris-flow effects from these storms were minimal in the southern Coast Range (Wiley, 2000).

The Oregon State Highway 38 corridor through the southern Coast Range is one of the most hazardous debrisflow areas in Oregon, yet much previous debris-flow mapping in the area was limited to point data along the highway (Hofmeister, 2000), which is not particularly well-suited for debris-flow process studies or as "ground truth" for predictive maps of debris-flow hazard. Work by the Oregon Department of Forestry following debris flows in 1996 was an exception to this statement (Robison and others, 1999). Work by Robison and others consisted of detailed field mapping of debris-flow source areas and effects on channels in two areas south of Scottsburg, Oregon. Griswold and Iverson (2007) used part of this mapping to estimate debris-flow travel distances and effects on debris fans using the debris-flow modeling program LAHARZ (Schilling, 1998; Iverson and others, 1998). 




Figure 1. Index map showing the location of the map area with respect to the Reedsport and Deer Head Point 1:24,000-scale USGS topographic quadrangles.

Our work expands on this previous work by providing detailed debris-flow mapping in a 94.4 square kilometer $\left(\mathrm{km}^{2}\right)$ area along Highway 38 between Reedsport and Scottsburg (fig. 1 and map). Our mapping identifies debris-flow source areas, areas of predominantly erosion, transport or mixed erosion and deposition, and areas of deposition. We used newly available (2009), high resolution (0.91 m cells (3 ft.)), airborne Light Detection And Ranging (LiDAR) data from the Oregon Department of Geology and Mineral Industries (DOGAMI) as the topographic base for our mapping.

\section{Setting}

The map area is between Reedsport and Scottsburg, Oregon, and is transected by the Umpqua River and Highway 38. Elevations in the map area range from about $2 \mathrm{~m}$ above sea level along the Umpqua River to about $490 \mathrm{~m}$ at the summit of Deer Head Point (see map). The area has a maritime climate with wet winters and dry summers. Average annual precipitation ranges from about 1,520 to 2,540 $\mathrm{mm}$ (PRISM Climate 
Table 1. Rain-gage station information

\begin{tabular}{|l|c|c|c|r|}
\hline \multicolumn{1}{|c|}{ Gage name } & $\begin{array}{c}\text { National Weather } \\
\text { Service (NWS) ID }\end{array}$ & Latitude & Longitude $^{1}$ & $\begin{array}{c}\text { Elevation } \\
\text { (m) }\end{array}$ \\
\hline Goodwin Peak & 352545 & $43^{\circ} 55^{\prime} 41^{\prime \prime}$ & $123^{\circ} 53^{\prime} 25^{\prime \prime}$ & 557 \\
\hline Gardiner & 353193 & $43^{\circ} 45^{\prime} 00^{\prime \prime}$ & $124^{\circ} 07^{\prime} 00^{\prime \prime}$ & 9 \\
\hline North Bend & 356073 & $43^{\circ} 25^{\prime} 00^{\prime \prime}$ & $124^{\circ} 15^{\prime} 00^{\prime \prime}$ & 37 \\
\hline Elkton & 352633 & $43^{\circ} 36^{\prime} 00^{\prime \prime}$ & $123^{\circ} 35^{\prime} 00^{\prime \prime}$ & \\
\hline
\end{tabular}

Group, 2006). The wet and relatively warm climate results in a coastal forest dominated by Douglas fir, western hemlock, red alder, and a variety of understory shrubs. Trees are harvested throughout the map area, usually by commercial clear-cut operations.

Tertiary marine sandstones and siltstones of the Tyee Formation (Niem and Niem, 1990; Walker and MacLeod, 1991) underlie the area. The drainage network is dense, with a dendritic pattern that has often been characterized as highly dissected (for example, Benda, 1990). Hillslopes are short, steep, and typically mantled by 0.5 to $3 \mathrm{~m}$ of colluvial soil (Dietrich and Dunne, 1978; Reneau and Dietrich, 1991; Montgomery and others, 2002). Debris flows typically mobilize from small slides in concave hillslope areas and increase in volume by erosion and entrainment of downslope channel sediment before depositing material in higher order drainage channels and on fans (Benda and Cundy, 1990). Woody debris is often incorporated into debris flows, and woody-debris jams often influence the locations of debris-flow deposition (Montgomery and others, 2003).

\section{Rainfall in November, 1996}

Four rain gages were operating in the vicinity of the study area in 1996 (figs. 1 and 2). Three gages, Gardiner, North Bend, and Elkton, were located at National Weather Service (NWS) Cooperative Network stations, and the fourth, Goodwin Peak, was at a U.S. Forest Service Remote Automatic Weather Station (RAWS). The Gardiner and North Bend stations were along the Pacific coast at elevations of $9 \mathrm{~m}$ and $2 \mathrm{~m}$, respectively. The Goodwin Peak gage was within the Coast Range at an elevation of $557 \mathrm{~m}$. The Elkton gage was on the eastern (leeward) flank of the Coast Range at an elevation of $37 \mathrm{~m}$.

Cumulative rainfall in 1996 was greatest at Goodwin Peak (3,232 mm, fig. 2A) and lowest at Elkton (2,163 mm). Cumulative rainfall at Gardiner and North Bend was 2,418 mm and 2,182 $\mathrm{mm}$, respectively. Seasonal antecedent rainfall from the beginning of the fall/winter wet season on October 1, 1996, to the start of the November 17-19 storm was $441 \mathrm{~mm}, 232$ $\mathrm{mm}, 256 \mathrm{~mm}$, and $201 \mathrm{~mm}$ at Goodwin Peak, Gardiner, North Bend, and Elkton, respectively. With the exception of Elkton rainfall, all of these rainfall values exceed the antecedent rainfall threshold of $203 \mathrm{~mm}$ defined by Wiley (2000) as necessary for debris-flow occurrence in Oregon.
The November 17-19 storm was the result of an extensive system of moist subtropical air that originated over the tropical Pacific and spread from south to north across Oregon (George Taylor, Oregon Climate Service, unpublished data, 1997). More recent terms used to describe this type of weather system are "Pineapple Express" or "Atmospheric River" (for example, see Junker and others, 2009). Total rainfall during the 3-day storm was $245 \mathrm{~mm}, 254 \mathrm{~mm}, 231 \mathrm{~mm}$, and $143 \mathrm{~mm}$ at Goodwin Peak, Gardiner, North Bend, and Elkton, respectively. Hourly rainfall during the storm was collected at the Goodwin Peak and Elkton gages (fig. $2 \boldsymbol{B}$ ). The storm had a mean intensity of $4.9 \mathrm{~mm} / \mathrm{hr}$ for 47 hours at Goodwin Peak and $3.4 \mathrm{~mm} / \mathrm{hr}$ for 39 hours at Elkton. Maximum rainfall intensity was almost two times greater at Goodwin Peak (13.2 $\mathrm{mm} / \mathrm{hr}$ for one hour on November 18) than at Elkton (7.4 $\mathrm{mm} / \mathrm{hr}$ for two hours on the 18th). Based on the comparable positions of the Goodwin Peak gage and the map area within the core of the Coast Range, rainfall within the map area was probably most similar to that at Goodwin Peak.

\section{Map Description}

\section{Mapping Debris Flows}

Initially, we mapped debris flows from 1:12,000-scale, color, stereo aerial photographs onto a topographic base map using a Kern PG-2 photogrammetric plotter (Pillmore, 1989). The PG-2 had 5×, 10×, and $20 \times$ zoom magnification capabilities. The topographic base map used on the PG-2 was created by plotting digital versions of the Deer Head Point and Reedsport U.S. Geological Survey (USGS) 7.5-minute quadrangles at 1:12,000 scale. The aerial photographs were flown in May 1997. The 1:12,000 scale of the photography allowed us to accurately identify debris-flow features as small as about $1 \mathrm{~m}$ in clear-cut areas. For areas under trees, our ability to identify debris-flow features was highly variable and poorly constrained. Debris flows were mapped if their features were fresh, that is, they had a lighter tone than their surroundings (fig. 3). Many parts of the study area had dense tree cover making it difficult to see complete paths affected by debris flows. We extended mapped debris flows through these areas if we saw obvious evidence for debris flows in upstream and downstream locations. 

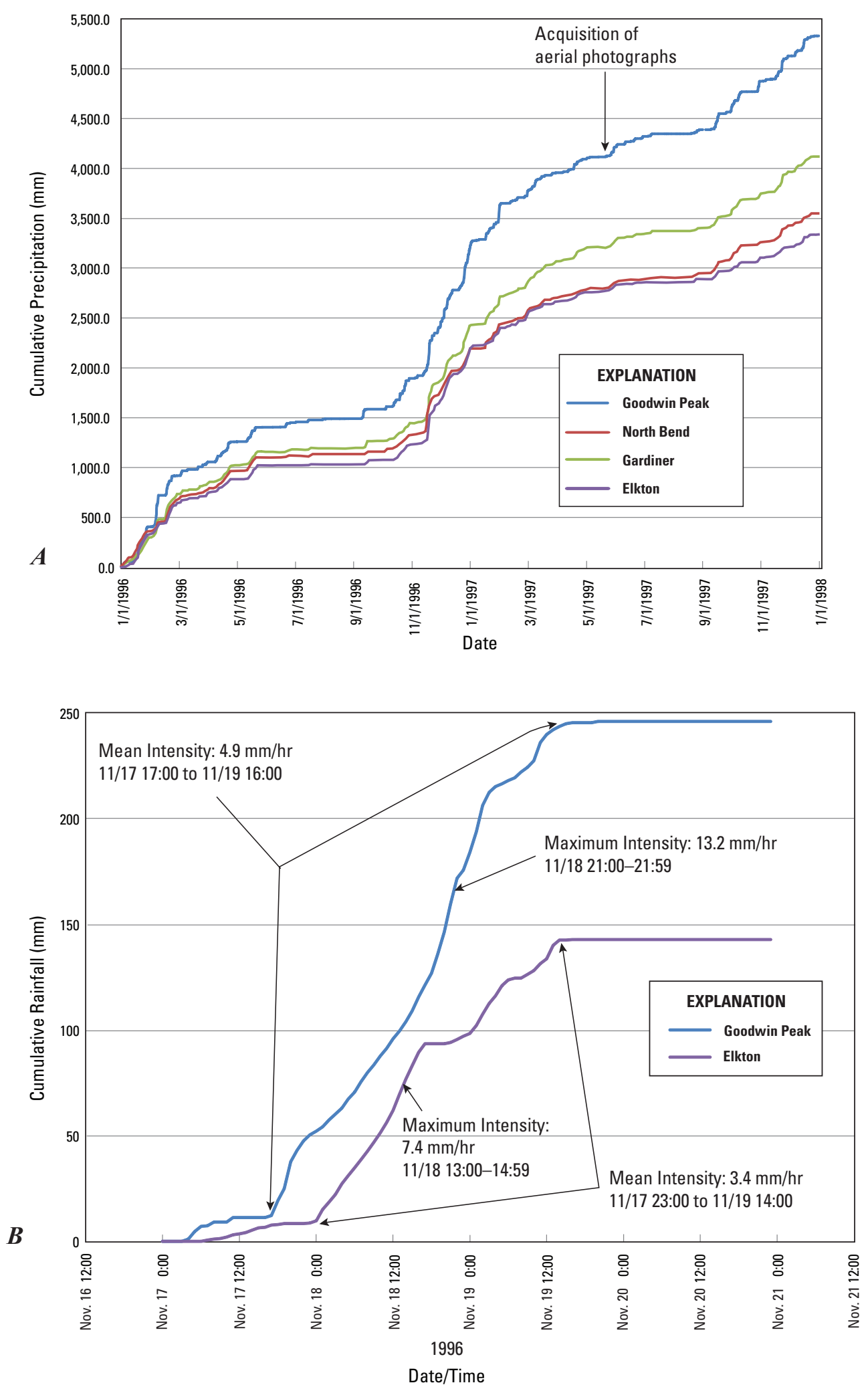

Figure 2. Diagram showing $\boldsymbol{A}$, cumulative precipitation during 1996 and 1997 , and $\boldsymbol{B}$, cumulative hourly rainfall during the November 17-19 rainstorm. See figure 1 for rain gage locations. 
Work by Brardinoni and others (2003) and Robison and others (1999) indicates that most (up to 85 percent and greater than 95 percent, respectively) landslides (or debris flows) may be missed by conventional aerial photographic interpretation in mature forested areas of the Pacific Northwest. Conventional aerial photographic interpretation and mapping consists of landslide identification using a desktop stereoscope (typically with $3 \times$ to $8 \times$ magnification) and manual transfer of identified landslides to a topographic base map. Even though our photogrammetric methods utilized more sophisticated equipment with higher magnification, we acknowledge that fewer debris flows are shown on the map compared to the unknown actual number of flows that occurred in 1996.

\section{Subdivision of Debris Flows}

During mapping, debris flows were subdivided into discrete slide source areas, areas dominated by erosion, those dominated by transport or mixed erosion and deposition, and areas dominated by deposition. We follow Varnes (1978) terminology and define "slide" as a displaced mass where movement has occurred by shear displacement along one or more surfaces. Discrete slides were mapped where we could see or interpret both the upslope and downslope extent of failures. Areas mapped as discrete slides included both evacuated areas (scars) and deposits. The downslope extent of discrete slides could often be defined as the location where the width of the failure narrowed and became channelized. At the heads of many mapped debris flows, we observed a headscarp and downslope erosion, but no indicator of the downslope extent of failure. These areas were mapped as eroded areas with no discrete landslide source area. Eroded areas were devoid of vegetation, topographically concave, very light in color, and exhibited sharp tonal contrast compared to vegetated surroundings (fig. 3). Areas dominated by deposition tended to have topographically convex or planar surface morphologies that were more jumbled (rougher) than eroded areas. Remnants of in-situ vegetation (for example, standing trees) were sporadically present in some deposition areas. In areas mapped as transport zones or as areas of mixed erosion and deposition, pre-flow topographic surfaces were visible, or surfaces exhibited features suggestive of both erosion and deposition (described above). Woody-debris jams were mapped in locations where we observed topographically convex bumps in channels that contained large tree trunks. Sediment deposition was often located upstream from these jams.

Based on the prevalence of debris flows in the southern Coast Range in 1996 (Robinson and others, 1999; Hofmeister, 2000; Squier and Harvey, 2000; Wiley, 2000), we infer that debris flows were responsible for creating the areas of erosion, transport, and deposition shown on the map. However, as debris flows and water-dominated flows (floods) can often occur together on the west coast of the United States (for example, Ellen and Wieczorek, 1988), it is possible that flooding also contributed to the formation of features in the mapped areas. Also, modification of mapped features by running water or additional debris flows between the November 1996 storm and the May 1997 acquisition of aerial photography is also possible. We could not account for these possibilities in our mapping.

Once mapped, debris flows were digitized from the 1:12,000-scale, quadrangle-based maps into the Environmental Systems Research Institute, Inc. $\left(\mathrm{ESRI}^{\circledR}\right)$ ArcGIS $^{\circledR}$ and then transferred to a LiDAR-derived, shaded-relief base map. The LiDAR data were acquired in 2008 and became available to us in August 2009. The shaded-relief base map has $0.91 \mathrm{~m}(3.00$ $\mathrm{ft})$ cells and is illuminated from an azimuth of 315 degrees and a vertical angle of 45 degrees. The process of transferring mapped debris flows to the LiDAR map was difficult because the topographic details visible in the LiDAR were often not visible in, or were different from, the more generalized topography onto which the debris flows were initially mapped. When we transferred the debris flows, we attempted to retain their original shapes and sizes as much as possible. In general, travel distance lengths were not affected during the transfer process, and debris flow widths were minimally affected. However, in many instances, the debris-flow polygons, particularly in steep channel areas, had to be moved laterally by about $25 \mathrm{~m}$ (about $2 \mathrm{~mm}$ at 1:12,000-scale) to properly fit the LiDAR topography. Steep channels were the typical areas where this was a problem. There, large portions of debrisflow travel paths mapped onto the USGS quads often did not occupy channel bottoms on the LiDAR map, but rather were located entirely on side slopes of channels. In order to correct this situation, debris flows were moved laterally until they were positioned within channel bottoms on the LiDAR map.

\section{Field Checking}

We did not systematically field check our mapping because most areas that were affected by debris flows in 1996 were covered by vegetation in 2008 and 2009 when we did our mapping from aerial photographs. Based on the sporadic field observations that we did make, we found that it was difficult to differentiate 1996 scars and deposits from pre- and post-1996 scars and deposits from field observations alone. Additionally, we observed that many (most?) of our mapped debris flows from 1996 could not be identified using the 2008 LiDAR data alone. This observation indicated that it would be difficult to use LiDAR alone, without any supplemental information from aerial photographs, satellite images, or field work to map the relatively small, shallow debris flows that are common in heavily forested areas of the Pacific Northwest. This assertion is similar to that made by Burns and others (2010) in the northern Coast Range of Oregon.

\section{Debris-Flow Polygons}

The area encompassed by all types of debris-flow polygons (slide, erosion, transport, and deposition) was 2.0 $\mathrm{km}^{2}$, which is 2.1 percent of the $94.4 \mathrm{~km}^{2}$ map area. For 


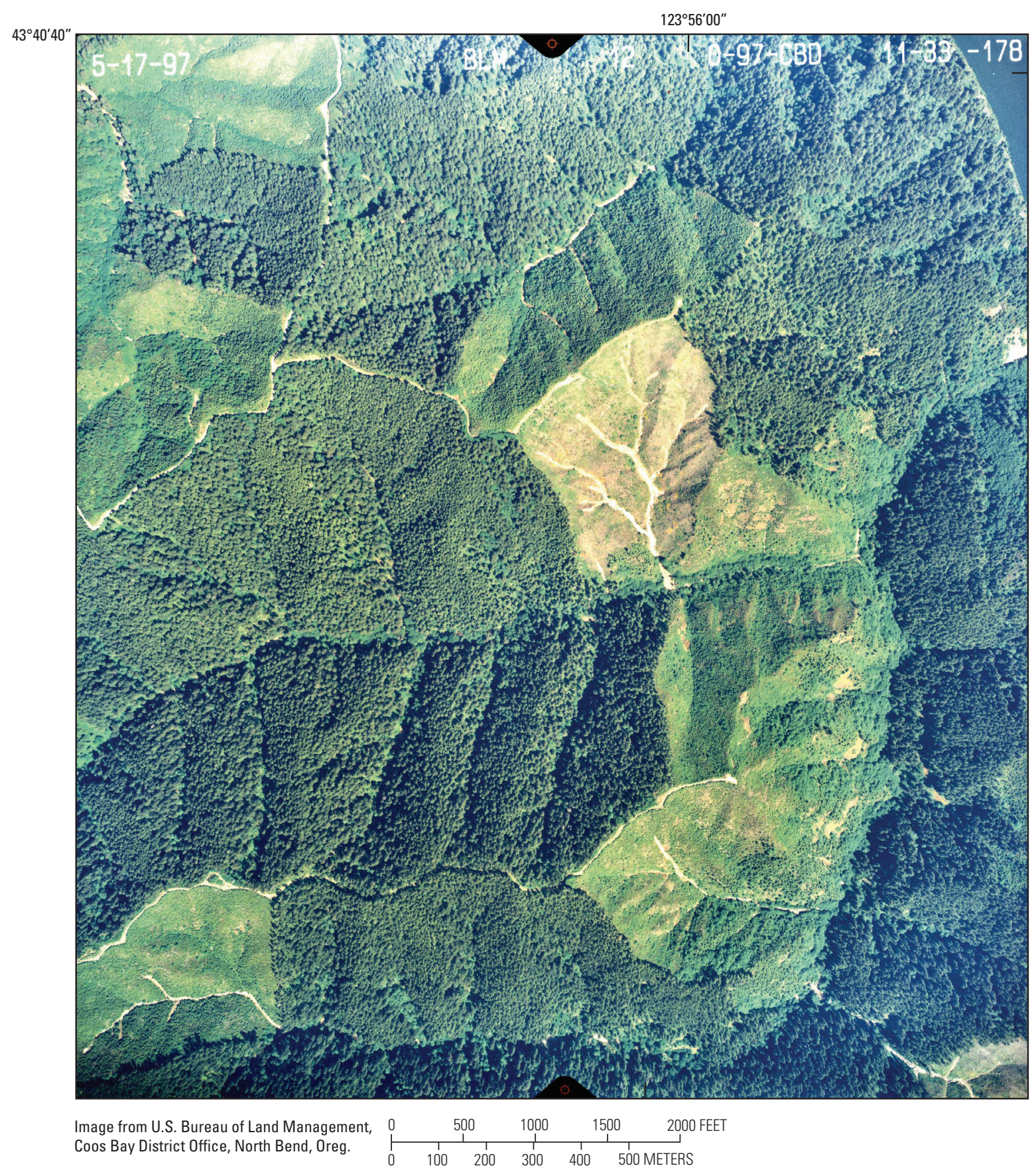

Figure 3. Example of a 1:12,000-scale aerial photograph used for mapping. Area covered by the photograph is shown on map.

the 155 discrete slide source areas mapped, the minimum, maximum, and mean sizes were $17 \mathrm{~m}^{2}, 1,685 \mathrm{~m}^{2}$, and 370 $\mathrm{m}^{2}$, respectively. Thus far, the map data have been used for evaluating predictions of debris-flow source areas (Baum and others, 2011), developing models for estimating debris-flow travel distances (Coe and others, 2011), and for estimating volumes of sediment eroded and entrained into debris flows for accurate predictions of debris-flow volumes expected in channels and at the mouths of drainage basins (Coe and Michael, 2009).

\section{Digital Data}

Digital data included with this map report include a polygon showing the extent of mapping, debris-flow polygons, woody-debris jam locations, and the bare-earth LiDAR data used for the base map. Data are available as ESRI ${ }^{\circledR}$ shape and grid files within a single zipped archive file. Debris-flow polygon data are not intended for use at scales larger than 1:12,000 (for example, 1:6,000). 


\section{Acknowledgments}

The authors thank Frank Price of the U.S. Bureau of Land Management in Coos Bay, Oregon, for lending us the aerial photographs used in this study. John Seward and Jason Hinkle of the Oregon Department of Forestry, and Bill Schulz and Jonathan Godt of the U.S. Geological Survey provided suggestions that improved the clarity of the report. Editing support provided by Lisa Binder, Denver Publishing Science Network.

\section{References}

Baum, R.L., Godt, J.W., and Coe, J.A., 2011, Assessing susceptibility and timing of shallow landslide and debris flow initiation in the Oregon Coast Range, USA, in Genevois, R., Hamilton, D.L., and Prestininzi, A., eds., Proceedings of the 5th international conference on debrisflow hazards mitigation, mechanics, prediction and assessment, Padua, Italy, June 14-17, 2011, Italian Journal of Engineering Geology and Environment, and Casa Editrice Universita La Sapienza, Rome, p. 825-834.

Benda, L.E., 1990, The influence of debris flows on channels and valley floors in the Oregon Coast Range, U.S.A.: Earth Surface Processes and Landforms, v. 15, p. 457-466.

Benda, L.E., and Cundy, T.W., 1990, Predicting deposition of debris flows in mountain channels: Candadian Geotechnical Journal, v. 27, p. 409-417.

Brardinoni, Francesco, Slaymaker, Olav, and Hassan, M.A., 2003, Landslide inventory in a rugged forested watershedA comparison between air-photo and field survey data: Geomorphology, v. 54, p. 179-196.

Burns, W.J., Coe, J.A., Sener-Kaya, Basak, Ma, Lina, 2010, Analysis of elevation changes detected from multi-temporal LiDAR surveys in forested landslide terrain in western Oregon: Environmental \& Engineering Geoscience, v. 16, no. 4 , p. $315-341$.

Coe, J.A., and Michael, J.A., 2009, Quantitative analysis of channel erosion by debris flows, central Coast Range, Oregon [abs.]: Geological Society of America Abstracts with Programs, v. 41, no. 7, p. 610.

Coe, J.A., Reid, M.E., Brien, D.L., and Michael, J.A., 2011, Assessment of topographic and drainage network controls on debris-flow travel distance along the west coast of the United States, in Genevois, R., Hamilton, D.L., and Prestininzi, A., eds., Proceedings of the 5th International Conference on debris-flow hazards mitigation, mechanics, prediction and assessment, Padua, Italy, June 14-17, 2011, Italian Journal of Engineering Geology and Environment, and Casa Editrice Universita La Sapienza, Rome, Italy, p. 199-209.
Dietrich, W.E., and Dunne, Thomas, 1978, Sediment budget for a small catchment in mountainous terrain: Zietschrift für Geomorphologie, Supplement Band 29, p. 191-206.

Ellen, S.D., and Wieczorek, G.F., eds., 1988, Landslides, floods, and marine effects of the storm of January 3-5, 1982, in the San Francisco Bay Region, California: U.S. Geological Survey Professional Paper 1434, 310 p.

Griswold, J.P., and Iverson, R.M., 2007, Mobility statistics and automated hazard mapping for debris flows and rock avalanches: U.S. Geological Survey Scientific Investigations Report 2007-5276, 59 p.

Hofmeister, R.J., 2000, Slope failures in Oregon, GIS inventory for three 1996/97 storm events: Oregon Department of Geology and Mineral Industries Special Paper 34, 20 p.

Iverson, R.M., Schilling, S.P., and Vallance, J.W., 1998, Objective delineation of lahar-hazard inundation zones: Geological Society of America Bulletin, v. 110, no. 8, p. 972-984.

Junker, N.W., Brennan, M.J., Pereira, Frank, Bodner, M.J., and Grumm, R.H., 2009, Assessing the potential for rare precipitation events with standardized anomalies and ensemble guidance at the hydrometeorological prediction center: Bulletin of the American Meteorological Society, v. 90 , no. 4 , p. $445-453$.

May, C.L., and Gresswell, R.E., 2004, Spatial and temporal patterns of debris-flow deposition in the Oregon Coast Range, USA: Geomorphology, v. 57, p. 135-149.

Mills, K.A. and Hinkle, J.C., eds., 2001, Forestry, landslides, and public safety-An issue paper prepared for the Oregon Board of Forestry: Oregon Department of Forestry, 81 p., 6 appendixes.

Montgomery, D.R., Dietrich, W.E., and Heffner, J.T., 2002, Piezometric response in shallow bedrock at $\mathrm{CB} 1-$ Implications for runoff generation and landsliding: Water Resources Research, v. 38, no. 12, 1274, 18 p., doi:10.1029/2002WR001429.

Montgomery, D.R., Massong, T.M., and Hawley, S.C.S., 2003, Influence of debris flows and log jams on the location of pools and alluvial channel reaches, Oregon Coast Range: Geological Society of America Bulletin, v. 115, p. 78-88.

Niem, A.R., and Niem, W.A., 1990, Geology and oil, gas, and coal resources, southern Tyee Basin, southern Coast Range, Oregon: Oregon Department of Geology and Mineral Industries Open-File Report O-89-3, 44 p. pamphlet, 3 plates, 1:125,000 scale.

Pillmore, C.L., 1989, Geologic photogrammetry in the U.S. Geological Survey: Photogrammetric Engineering and Remote Sensing, v. 55, p. 1185-1189. 
PRISM Climate Group, 2006, Average annual precipitation, 1971-2000, Oregon: Corvallis, Oregon State University, PRISM Climate Group and Oregon State Climate Service, accessed on Feb. 28, 2011 at http://www.prism.oregonstate. edu/state_products/index.phtml?id=OR.

Reneau, S.L., and Dietrich, W.E., 1991, Erosion rates in the southern Oregon Coast Range-Evidence for an equilibrium between hillslope erosion and sediment yield: Earth Surface Processes and Landforms, v. 16, p. 307-322.

Robison, E.G., Mills, K.A., Paul, Jim, Dent, Liz, and Skaugset, A.E., 1999, Storm impacts and landslides of 1996Final Report: Oregon Department of Forestry, Forestry Practices Technical Report no. 4, 145 p.

Schilling, S.P., 1998, LAHARZ-GIS program for automated mapping of lahar-inundation hazard zones: U.S. Geological Survey Open-File Report 98-638, 80 p.

Squier, L.R., and Harvey, A.F., 2000, Two debris-flows in Coast Range, Oregon, USA — Logging and public policy impacts, in Wieczorek, G.F., and Naeser, N.D., eds., Debris flow hazards mitigation, mechanics, prediction and assessment, Proceedings of the second international conference on debris-flow hazards mitigation, Taipei, Taiwan, Aug. 16-18, 2000: Rotterdam, Aa Balkema, Rotterdam, p. 127-138.

Varnes, D. J., 1978, Slope movement types and processes, in Schuster, R.L., and Krizek, R.J., eds., Landslides Analysis and Control: Transportation Research Board Special Report 176, National Research Council, National Academy Press, Washington, DC, p. 11-33.

Walker, G.W., and MacLeod, N.S., 1991, Geologic map of Oregon: U.S. Geological Survey, 2 sheets, scale 1:500,000.

Wiley, T.J., 2000, Relationship between rainfall and debris flows in western Oregon: Oregon Geology, v. 62, no. 2, p. $27-43$. 
Publishing support provided by:

Denver Publishing Service Center

For more information concerning this publication, contact: Center Director, USGS Geologic Hazards Science Center Box 25046, Mail Stop 966

Denver, CO 80225

(303) 273-8579

Or visit Geologic Hazards Science Center Web site at: http://geohazards.cr.usgs.gov/ 